Patricia Canto • Irineo Escudero • Daniela Söderlund

Elisa Nishimura $\cdot$ Sebastian Carranza-Lira

Jesus Gutierrez • Andres Nava • Juan Pablo Mendez

\title{
A novel mutation of the insulin-like 3 gene in patients with cryptorchidism
}

Received: October 15, 2002 / Accepted: November 13, 2002

\begin{abstract}
Two independent studies demonstrated that transgenic mice with a targeted deletion of the insulin-like 3 (INSL3) gene presented bilateral cryptorchidism. Studies in humans have investigated the possibility that mutations in the INSL3 gene are the cause of cryptorchidism. In the present study, genomic DNA was obtained from 150 patients with idiopathic cryptorchidism. DNA was amplified and the polymerase chain reaction products of both exons were sequenced. A previously unidentified missense mutation was found in only one of the patients studied. In exon 2, a heterozygous $\mathrm{C} / \mathrm{G}$ substitution at nucleotide 2560 , which turned asparagine into lysine at codon 86 , was documented. The familial study revealed that the mother was a heterozygous carrier of the mutation and the father was a
\end{abstract}

P. Canto $\cdot$ I. Escudero $\cdot$ D. Söderlund $\cdot$ J.P. Mendez

Research Unit in Developmental Biology, Hospital de Pediatría,

Centro Médico Nacional Siglo XXI, Instituto Mexicano del Seguro

Social, México, D.F., México

E. Nishimura

Department of Endocrinology, Hospital de Pediatría, Centro Médico Nacional Siglo XXI, Instituto Mexicano del Seguro Social, México,

D.F., México

S. Carranza-Lira

Gynecologic Endocrinology Service, Hospital de Ginecología y Obstetricia Luis Castelazo Ayala, Instituto Mexicano del Seguro Social, México, D.F., México

J. Gutierrez

Pediatric Surgery Service, Hospital Gonzalo Castañeda, Instituto de Seguridad y Servicios Sociales para los Trabajadores del Estado, México, D.F., México

A. Nava

Pediatric Urology Service, Hospital Adolfo López Mateos, Instituto de Seguridad y Servicios Sociales para los Trabajadores del Estado, México, D.F., México

J.P. Mendez $(\bowtie)$

Unidad de Investigación Médica en Biología del Desarrollo, Coordinación de Investigación en Salud, Coahuila 5, Apartado

Postal A-047, Colonia Roma, C.P. 06703, México, D.F., México

Tel. +52-55-5687-72-55; Fax +52-55-5761-09-52

e-mail: jpmb@servidor.unam.mx homozygote wild type. We also found three polymorphic changes, previously reported in exon 1 . The Asn-intoLys change is likely deleterious because it leads to a nonconservative amino acid substitution, changing a highly conserved residue. This mutation, located in the A-chain of the INSL3 protein, is the first mutation reported in this region. This finding provides new evidence that INSL3 is involved in testicular descent in humans; however, mutations of this gene are not a frequent cause of cryptorchidism.

Key words Cryptorchidism - INSL3 gene - Mutation . Genomic DNA · Sequancing analyses

\section{Introduction}

Male phenotypic development is a complex process in which many genes and hormonal factors intervene. Although many of the underlying mechanisms have been established, testicular descent to the scrotum has not been perfectly elucidated. During testicular descent in the normal male fetus, the developing testis migrates from its initial position high in the abdomen into the scrotum. The differential development of two ligaments of the genital mesentery - the gubernaculum and the cranial suspensory ligament - determines the dimorphic position of the existing gonad. This process comprises a transabdominal phase in which the development of the gubernaculum and the regression of the cranial suspensory ligament result in the migration of the testis into the inguinal region and an inguinoscrotal phase in which the testis descends to the base of the scrotum. In humans, the first phase of testicular descent occurs between 10 and 15 weeks of gestation; and the second phase occurs at 28-35 weeks of gestation (Hutson et al. 1997).

Undescended testes affect $3.4 \%$ to $5.1 \%$ of all male infants at birth (Scorer 1964; John Radcliffe Hospital Cryptorchidism Study Group 1992), but less than half of them persist with the abnormality at 1 year of age (Thong et al. 
1998). Cryptorchidism is associated with a higher risk of developing testicular tumors in adulthood, the risk being five- to tenfold greater than in normal men (Woodhouse 1991; United Kingdom Testicular Cancer Study Group 1994). To produce viable and mature spermatozoa, testicular temperature must be $1.5^{\circ} \mathrm{C}-2.0^{\circ} \mathrm{C}$ below body temperature; thus undescended testes also cause infertility (Leissner et al. 1999).

Because testicular descent requires various changes in both ligaments, several testicular factors have been investigated (van der Schoot and Elger 1992; Behringer et al. 1994; van der Schoot et al. 1995; Mishina et al. 1996; Emmen et al. 1998). These studies suggested that a specific factor (descendin) mediated testicular descent (Husmann and Levy 1995). Recently, insulin-like 3 (INSL3), a member of the insulin-like hormone superfamily that is specifically expressed in fetal and adult Leydig cells and is involved in testicular descent, has been characterized (Adham et al. 2000). The gene and its protein product have been identified in several species (Adham et al. 1993; Burkhardt et al. 1994; Bathgate et al. 1996; Pusch et al. 1996; Roche et al. 1996; Zarreh-Hoshyari-Khah et al. 1999). This hormone has a sexually dimorphic expression in mice; analyses of gene transcripts have revealed fetal testes transcripts at embryonic day 13.5, whereas no transcripts were detected in fetal ovaries (Zimmermann et al. 1997). Two independent studies have demonstrated that transgenic mice with targeted deletion of this gene presented bilateral cryptorchidism, as well as other sexual abnormalities (Nef and Parada 1999; Zimmermann et al. 1999). Several studies in humans investigated the possibility that mutations in the INSL3 gene were the cause of cryptorchidism; however, three mutations have been documented in only two of these studies (Tomboc et al. 2000; Marin et al. 2001b).

Here we report the molecular findings regarding the INSL3 gene in 150 unrelated patients with unilateral or bilateral cryptorchidism.

\section{Patients and methods}

\section{Patients}

Blood samples for extraction of genomic DNA were obtained from 150 patients with idiopathic unilateral (left, $n=48$; right, $n=57)$ or bilateral $(n=45)$ cryptorchidism (or history of cryptorchidism), as well as from 50 male controls. All individuals were of Mexican mestizo ethnic origin; the families were not related. All individuals were products of uneventful pregnancies and none of them was born preterm. The family history was obtained from the patients or from their parents, with a cryptorchid first-degree relative documented in the families of 27 patients. Ages of the subjects ranged from 2 months to 27 years. The study was approved by the Institute's Human Research Committee; written informed consent was obtained from all adult participants and from the parents of all children.
Methods

Genomic DNA was isolated from the blood leukocytes of all patients, as well as from normal male controls by standard techniques (Sambrook et al. 1989). DNA prepared from blood was amplified by polymerase chain reaction (PCR) in $50 \mu \mathrm{l}$ of reaction mixture containing $0.5 \mu \mathrm{g}$ genomic DNA, $200 \mu \mathrm{M}$ each deoxyribonucleotide triphosphate, 2.0 U of Thermostable DNA polymerase (AmpliTaq, Applied Biosystems, Foster City, CA, USA), and $0.4 \mu \mathrm{M}$ of each specific set of primers. The INSL3 primers for both exons were previously described by Tomboc et al. (2000):

\section{exon 1: 5'-TGGGAGAAAGGCTCTGGCAC-3' 5'-CTGGGCTCATGCATGCAAAC-3'}

exon 2: 5'-TGCATGCATGAGTGTTTGGTGGG-3' 5'-ATCAGTAGGGACAGAGGGTC-3'

PCR conditions for both exons were $94^{\circ} \mathrm{C}$ for $5 \mathrm{~min}$ followed by 30 cycles of $94^{\circ} \mathrm{C}$ for $1 \mathrm{~min}, 64^{\circ} \mathrm{C}$ for $1 \mathrm{~min}$, and $72^{\circ} \mathrm{C}$ for $1 \mathrm{~min}$. This was terminated by $72^{\circ} \mathrm{C}$ for $7 \mathrm{~min}$.

After amplification, PCR products were electrophoresed on $1.2 \%$ agarose gels and stained with ethidium bromide to verify the correct size of the expected fragments $(452 \mathrm{bp}$ for exon one; $325 \mathrm{bp}$ for exon two).

PCR products were purified using the Qiaex II gel extraction kit (Qiagen GmbH, Hilden, Germany). These products were then sequenced $(0.01 \mu \mathrm{g}$ DNA template reaction) on an ABI 377 automated DNA sequencer (PerkinElmer, Applied Biosystems Division) using the BigDye Terminator Cycle Sequencing Ready Reaction kit (PerkinElmer). PCR conditions were identical to those described earlier. In all cases, both strands were sequenced and compared.

Each mutation or sequence variation was confirmed in three independent PCR amplification and sequencing analyses.

\section{Results}

Direct sequencing of both exons of the INSL3 gene in all 150 patients revealed a previously unidentified heterozygous missense mutation in only one of the patients studied. The propositus presented at our outpatient clinic at the age of 3 years and 5 months because of a right undescended testis that was localized, at the time of surgical correction, within the right inguinal canal. The left testis was located in the scrotum and had a volume of $2.3 \mathrm{ml}$. Penis length was $3.5 \mathrm{~cm}$ and there was no genital ambiguity. There was no family history of cryptorchidism; the patient had no siblings. Sequence analysis showed, in exon 2, a heterozygous C-toG substitution at nucleotide 2560, turning asparagine into lysine at codon 86. Sequence analysis from DNA samples obtained from both parents of the propositus was also examined. The mother was a heterozygous carrier of the 2560 $\mathrm{C} \rightarrow \mathrm{G}$ mutation. The father was a homozygote wild type (Fig. 1). Fifty normal male individuals (100 alleles) did not 


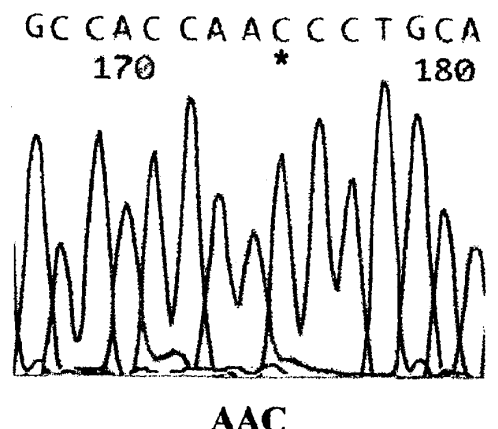

AAC

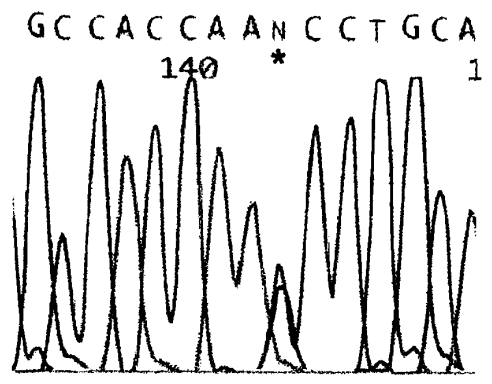

AAC/G

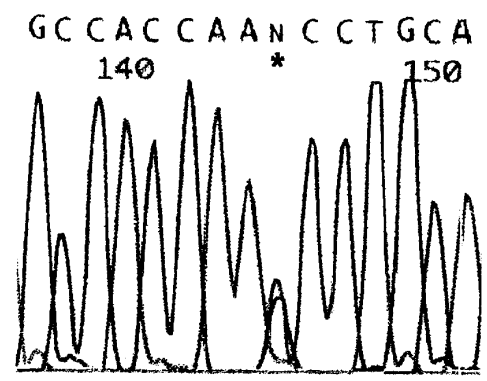

AAC/G

\section{Asn 86 Lys}

Fig. 1. Partial sequence of exon 2 of the INSL3 gene of a patient $(P)$ with unilateral (right) cryptorchidism, his father $(F)$, and his mother $(M)$. A heterozygous cytosine-to-guanine $(\mathrm{C} / \mathrm{G})$ mutation that results

harbor the mutation at nucleotide 2560 , being homozygous wild type.

Likewise, we found three different polymorphic changes previously reported in exon 1 . The first is a G-to-A substitution at nucleotide 1167 encoding alanine; this change did not alter the encoded amino acid. The second variation was detected in nucleotide 1266, in which a G-to-A substitution did not change the encoded amino acid (leucine). Finally, we found a G-to-A substitution at nucleotide 1318, which turned alanine into threonine. These changes were also found in the controls studied.

\section{Discussion}

Undescended testes are associated with infertility and a higher risk of developing testicular neoplasms (Scorer 1964; John Radcliffe Hospital Cryptorchidism Study Group 1992). Cryptorchidism can be unilateral or bilateral and, on the basis of its location, can be classified as abdominal, canalicular, ectopic, or retractile (Leissner et al. 1999). The abdominal testis is often located at the internal inguinal ring, the canalicular testis is located within the canal or at the top of the scrotum, and the ectopic testis is out of its normal pathway. Intracanalicular localization, where the cryptorchidic gonad of our patient with the missense mutation was located, has been found in $71.5 \%$ of patients with cryptorchidism (Cendron et al. 1993).

Although testicular descent to the scrotum has not been perfectly elucidated, it has been established that development of the gubernaculum and the cranial suspensory ligament determines testicular positioning. A testicular hormone involved in testicular descent (INSL3) was characterized by Adham et al. (2000). The gene that codifies this hormone is expressed predominantly in Leydig cells of fetal and adult testes, suggesting it is a marker of Leydig cell in the substitution of asparagine for lysine at codon 86 is observed in the patient and his mother

differentiation (Bamberger et al. 1999; Klonisch et al. 1999). This hormone has been demonstrated in human circulation (Bullesbach et al. 1999), and specific high-affinity INSL3 receptors have been identified, suggesting an endocrine role of INSL3 (Bullesbach and Schwabe 1999). Indeed, recently Kumagai et al. (2002) demonstrated that INSL3 is the cognate ligand for the LGR8 receptor, which is vital for testicular descent.

The studies performed by Zimmermann et al. (1999) and by Nef and Parada (1999) demonstrated that transgenic mice with targeted deletions of this gene presented bilateral cryptorchidism, infertility, normal male development of the external genitalia, and normal androgen-dependent conduct. These mice presented abnormalities in the development of the gubernaculum, normal Wolffian development, and absence of Müllerian duct structures, demonstrating that the function of this gene is independent from androgen and from Müllerian-inhibiting hormone. Based on this evidence, several studies in humans have investigated the possibility that mutations in the INSL3 gene are the cause of cryptorchidism; however, only in two of these studies were three causative mutations found (Tomboc et al. 2000; Marin et al. 2001b), whereas in other reports no mutations were documented (Koskimies et al. 2000; Krausz et al. 2000; Marin et al. 2001a).

After sequencing both exons of the INSL3 gene in 150 cryptorchidic individuals, we identified a causative mutation in one patient and three previously reported polymorphisms. The $2560 \mathrm{C} \rightarrow \mathrm{G}$ heterozygous mutation that changes codon 86 from asparagine into lysine was found in exon 2 of one propositus and his mother, whereas the father, 50 normal male controls, and all other 149 patients did not harbor this change, which also has not been found in any of the previous reported studies (Koskimies et al. 2000; Krausz et al. 2000; Tomboc et al. 2000; Marin et al. 2001a,b). The asparagine-into-lysine change is likely deleterious because it changes a polar amino acid into a basic amino acid, 
Table 1. Alignment of the human INSL3 sequences with other mammalian Insl3, demonstrating the highly conserved Asn86

\begin{tabular}{llll}
\hline A-chain & & $\mathbf{8 6}$ & Amino acids \\
\hline Patient & AAAT & $\mathbf{N} / \mathbf{K}$ & PARYCCLSGCTQQDLLTLCPY \\
Human (wt) & AAAT & $\mathbf{N}$ & PARYCCLSGCTQQDLLTLCPY \\
Marmoset monkey & AAAS & $\mathbf{N}$ & PARYCCLSGCSQQDLLTLCP \\
Cow & ATAI & $\mathbf{N}$ & PARHCCLSGCTRQDLLTLCPH \\
Sheep & ATAV & $\mathbf{N}$ & PARHCCLSGCTRQDLLTLCPH \\
Pig & AAAT & $\mathbf{N}$ & PARHCCLSGCTRQDLLTLCPH \\
Mouse & SAAT & $\mathbf{N}$ & AVHRCCLTGCTQQDLLGLCPH \\
\hline
\end{tabular}

Asn 86 is substituted with lysine in our patient. Amino acid 86 is depicted in bold type wt, Wild type

leading to a nonconservative amino acid substitution, changing a highly conserved residue (Table 1 ). This mutation is located in the A-chain of the INSL3 protein, constituting the first mutation reported in this region. This finding provides new evidence that INSL3 is involved in testicular descent in humans. Because this is a heterozygous mutation, haploinsufficiency is the likely mechanism.

Likewise, three different polymorphic changes that had been previously reported (Koskimies et al. 2000; Krausz et al. 2000; Tomboc et al. 2000; Marin et al. 2001a,b) were found in exon 1 in our patients and controls (nucleotides 1167, 1266, and 1318). Our study performed in the Mexican mestizo population confirms that these variants, which are common in other normal men with no history of cryptorchidism, are frequent in diverse ethnic groups.

This study extends previous reports demonstrating that mutations of the INSL3 gene are not a frequent cause of cryptorchidism. Tomboc et al. (2000) found two causative mutations in this gene in 145 cryptorchidic individuals; Marin et al. (2001b) found a mutation in ten patients studied; and Koskimies et al. (2000), Krausz et al. (2000), and Marin et al. (2001a) did not find mutations in this gene. Including our study, only four mutations have been observed in approximately 400 cryptorchidic patients studied, demonstrating that the frequency of INSL3 mutations as a cause of cryptorchidism is low. The reasons that mutations in this gene are not a common cause of human cryptorchidism have not been determined. The heterogeneity in the origin of this entity, as well as the presence of mutations in upstream activators, downstream targets of INSL3, the INSL3 receptor gene ( $L G R 8)$, or in other genes involved in testicular descent remain as plausible explanations for the origin of cryptorchidism.

Acknowledgments This work was supported by the Consejo Nacional de Ciencia y Tecnología (CONACyT), México; Grant: G29790M and by the Coordinación de Investigación en Salud, Instituto Mexicano del Seguro Social, México Grant: FP0038/1258. We thank Leonor Enciso from the Unidad de Instrumentos, Coordinación de Investigación en Salud, Instituto Mexicano del Seguro Social, for her technical assistance. Irineo Escudero is a postgraduate student from the Facultad de Medicina, Universidad Nacional Autónoma de México, México, D.F.

\section{References}

Adham IM, Burkhardt E, Benahmed M, Engel W (1993) Cloning of a cDNA for a novel insulin-like peptide of the testicular Leydig cells. J Biol Chem 268:26668-26672

Adham IM, Emmen JMA, Engel W (2000) The role of the testicular factor INSL3 in establishing the gonadal position. Mol Cell Endocrinol 160:11-16

Bamberger AM, Ivell R, Balvers M, Kelp B, Bamberger CM, Riethdorf L, Loning T (1999) Relaxin-like factor (RLF): a new specific marker for Leydig cells in the ovary. Int $\mathrm{J}$ Gynecol Pathol 18:163-168

Bathgate R, Balvers M, Hunt N, Ivell R (1996) Relaxin-like factor gene is highly expressed in the bovine ovary of the cycle and pregnancy: sequence and messenger ribonucleic acid analysis. Biol Reprod 55:1452-1457

Behringer RR, Finegold MJ, Cate RL (1994) Müllerian-inhibiting substance function during mammalian sexual development. Cell 79:415-425

Bullesbach EE, Schwabe C (1999) Specific, high affinity relaxin-like factor receptors. J Biol Chem 274:22354-22358

Bullesbach EE, Rhodes R, Rembiesa B, Schwabe C (1999) The relaxin-like factor is a hormone. Endocrine 10:167-169

Burkhardt E, Adham IM, Brosig B, Gastmann A, Mattei M-G, Engel W (1994) Structural organization of the porcine and human genes coding for a Leydig cell-specific insulin-like peptide (LEY I-L) and chromosomal localization of the human gene (INSL3). Genomics 20:13-19

Cendron M, Huff DS, Keating MA, Snyder HM, Duckett JW (1993) Anatomical, morphological and volumetric analysis: a review of 759 cases of testicular maldescent. J Urol 149:570-573

Emmen JMA, McLuskey A, Grootegoed JA, Brinkmann AO (1998) Androgen action during male sex differentiation includes suppression of cranial suspensory ligament development. Hum Reprod 13:1272-1280

Husmann DA, Levy JB (1995) Current concepts in the pathophysiology of testicular undescent. Urology 46:267-276

Hutson JM, Hasthorpe S, Heyns CF (1997) Anatomical and functional aspects of testicular descent and cryptorchidism. Endocr Rev 18:259-280

John Radcliffe Hospital Cryptorchidism Study Group (1992) Cryptorchidism: a prospective study of 7500 consecutive male births, 1984-8. Arch Dis Child 67:892-829

Klonisch T, Ivell R, Balvers M, Kliesch S, Fischer B, Bergmann M, Steger K (1999) Expression of relaxin-like factor is down-regulated in human testicular Leydig cell neoplasia. Mol Hum Reprod 5:104108

Koskimies P, Virtanen H, Lindström M, Kaleva M, Poutanen M, Huhtaniemi I, Toppari J (2000) A common polymorphism in the human relaxin-like factor $(R L F)$ gene: no relationship with cryptorchidism. Pediatr Res 47:538-541

Krausz C, Quintana-Murci Ll, Fellous M, Siffroi J-P, McElreavey $\mathrm{K}$ (2000) Absence of mutations involving the INSL3 gene in human idiopathic cryptorchidism. Mol Hum Reprod 6:298-302

Kumagai J, Hsu SY, Matsumi H, Roh J-S, Fu P, Wade JD, Bathgate RAD, Hsueh AJW (2002) INSL3/Leydig insulin-like peptide 
activates the LGR8 receptor important in testis descent. J Biol Chem 277:31283-31286

Leissner J, Filipas D, Wolf HK, Fisch M (1999) The undescended testis: considerations and impact on fertility. BJU Int 83:885-892

Marin P, Ferlin A, Moro E, Garolla A, Foresta C (2001a) Different insulin-like 3 (INSL3) gene mutations not associated with human cryptorchidism. J Endocrinol Invest 24:RC13-15

Marin P, Ferlin A, Moro E, Rossi A, Bartoloni L, Rossato M, Foresta C (2001b) Novel insulin-like 3 (INSL3) gene mutation associated with human cryptorchidism. Am J Med Genet 103:348-349

Mishina Y, Rey R, Finegold MJ, Matzuk MM, Josso N, Cate RL, Behringer RR (1996) Genetic analysis of the Müllerian-inhibiting substance signal transduction pathway in mammalian sexual differentiation. Genes Dev 10:2577-2587

Nef S, Parada LF (1999) Cryptorchidism in mice mutant for Insl3. Nat Genet 22:295-299

Pusch W, Balvers M, Ivell R (1996) Molecular cloning and expression of the relaxin-like factor from the mouse testis. Endocrinology 137:3009-3013

Roche PJ, Butkus A, Wintour EM, Tregar G (1996) Structure and expression of Leydig insulin-like peptide mRNA in the sheep. Mol Cell Endocrinol 121:171-177

Sambrook J, Fritsch EF, Maniatis T (1989) Isolation of high-molecular weight DNA from mammalian cells. In: Nolan C (ed) Molecular cloning: a laboratory manual. Cold Spring Harbor Laboratory Press, New York, pp 9.14-9.23

Scorer CG (1964) The descent of the testis. Arch Dis Child 39:605-609

Thong MK, Lim CT, Fatimah H (1998) Undescended testis: incidence in 1002 consecutive male infants and outcome at 1 year of age. Pediatr Surg Int 13:37-41
Tomboc M, Lee PA, Mitwally MF, Schneck FX, Bellinger M, Witchel SF (2000) Insulin-like 3/relaxin-like factor gene mutations are associated with cryptorchidism. J Clin Endocrinol Metab 85:40134018

United Kingdom Testicular Cancer Study Group (1994) Aetiology of testicular cancer: association with congenital abnormalities, age at puberty, infertility, and exercise. BMJ 308:1393-1399

van der Schoot P, Elger W (1992) Androgen-induced prevention of the outgrowth of cranial gonadal suspensory ligaments in fetal rats. J Androl 13:534-542

van der Schoot P, Vigier B, Prepin J, Perchellet JP, Gittenberger-de Groot A (1995) Development of the gubernaculum and processus vaginalis in freemartinism: further evidence in support of a specific fetal testis hormone governing male-specific gubernacular development. Anat Rec 241:211-224

Woodhouse CRJ (1991) Undescended testes. In: Woodhouse CRJ (ed) Long-term paediatric urology. Blackwell Scientific, Oxford, pp. 167175

Zarreh-Hoshyari-Khah MR, Einspanier A, Ivell R (1999) Differential splicing and expression of the relaxin-like factor gene in reproductive tissues of the marmoset monkey (Callithrix jacchus). Biol Reprod 60:445-454

Zimmermann S, Schöttler P, Elgel W, Adham IM (1997) Mouse Leydig-like ( $L E Y I-L)$ gene: structure and expression during testis and ovary development. Mol Reprod Dev 47:30-38

Zimmermann S, Steding G, Emmen JMA, Brinkmann AO, Nayernia K, Holstein AF, Engel W, Adham IM (1999) Targeted disruption of the Insl3 gene causes bilateral cryptorchidism. Mol Endocrinol 13:681-691 